GSA Data Repository item 2004013, methods, measurements, and uncertainties, Table DR1 (beryllium data for Wallowa moraines), and Figure DR1 (glacial deposits in Glacier Lake cirque area).

\title{
METHODS, MEASUREMENTS, AND UNCERTAINTIES
}

We followed several field procedures to minimize potential problems with prior exposure, erosion, post-depositional movement, and past burial (Licciardi, 2000). Although glacial polish and striae were rarely found, all sampled boulders in the Wallowa Mountains appeared relatively pristine and undisturbed, as evidenced by minimal surface pitting, and showed no evidence of spalling. Accordingly, no erosion corrections are applied. If we incorporate an erosion rate of $1.5 \mathrm{~mm} \mathrm{k.y.}{ }^{-1}$, a maximum likely rate for boulders of similar rock type in the Wind River Mountains (Gosse et al., 1995a, 1995b), the calculated ${ }^{10} \mathrm{Be}$ ages would increase by $<3.5 \%$. Preparation of samples for cosmogenic ${ }^{10} \mathrm{Be}$ measurements was performed following standard techniques of rock crushing and grinding, and isolation of quartz by repeated acid leaching (Kohl and Nishiizumi, 1992). Beryllium was extracted from the purified quartz by ion-exchange chemistry and selective precipitation techniques, following procedures developed by Licciardi (2000). The ${ }^{10}$ Be data, determined by accelerator mass spectrometry (AMS) at the PRIME Lab facility at Purdue University, are normalized with respect to a standard reference material (SRM 4325) obtained from the National Institute of Standards and Technology (Sharma et al., 2000). An adjustment was incorporated for the discrepancy of 14\% reported by Middleton et al. (1993) for SRM 4325 (see Table DR1).

All cosmogenic ${ }^{10} \mathrm{Be}$ ages were calculated using a high latitude, sea level production rate of $5.1 \pm$ 0.3 atoms $\mathrm{g}^{-1} \mathrm{yr}^{-1}( \pm 2 \sigma$; in quartz) (Stone, 2000; Gosse and Phillips, 2001), and the altitudinal and latitudinal scaling factors of Stone (2000) with a muonic production component of $2.6 \%$. In this paper,

${ }^{10}$ Be ages from the Wind River Mountains originally reported by Gosse et al. (1995a, 1995b) have been 
recalculated using these recently revised estimates of scaled production rates, and incorporate appropriate sample thickness and shielding corrections, but no snow or erosion corrections. No corrections are made for potential dipole-induced temporal variability of production rates at the field localities, and geographic latitude is used in production rate scaling (see Licciardi et al., 1999). The broad similarity in altitude, latitude, and age of calibration sites and samples minimizes systematic error contributed by production rate and scaling uncertainties (see Lal, 1991; Stone, 2000). Minimal shielding by surrounding topography $\left(<10^{\circ}\right)$ eliminates the need for a correction at the Wallowa Lake sites. For the Glacier Lake moraine, located in a high cirque (see Fig. DR1), corrections for shielding by topography and snow cover were necessary. The topographic shielding correction systematically increases the Glacier Lake exposure ages by ca. $2 \%$. Using the available 20 -year record of snow course data from the nearby Mt. Howard SNOTEL station (elevation $2411 \mathrm{~m}$ ) as a guide, we derive a snow cover correction that increases the ages by 3-9\% (following methods in Licciardi et al., 1999). The average daily water-equivalent snow cover for the available record is about $16.3 \mathrm{~cm}$ at Mt. Howard. The magnitude of the snow correction varies inversely with boulder height, and is largest (9\%) for the flat bedrock surface (GL-7).

As in previous work (Licciardi et al., 2001), we interpret the mean boulder exposure age as the best approximation for moraine age. We note that this approach, as applied to boulder exposure ages obtained by Gosse et al. (1995b) from the Pinedale terminal moraine complex in the Wind River Mountains, differs from the interpretation of these authors, who took the range spanned by the oldest and youngest exposure ages to indicate the duration of moraine occupation. For those boulders with duplicate analyses, the weighted mean of the two measurements is taken as the best representation of that boulder age. Outliers not included in weighted means were rejected following Chauvenet's criterion (see Bevington and Robinson, 1992). The errors quoted for the weighted mean ages of each moraine incorporate all propagated analytical uncertainties, but do not include the estimated error (ca. 6\%) in the production rate of cosmogenic ${ }^{10} \mathrm{Be}$, nor qualitative estimates of error imparted by scaling and other uncertainties (Licciardi et al., 2001). Gosse et al. (1995a, 1995b) assumed a uniform 3\% measurement uncertainty $(1 \sigma)$ for all ages, whereas the precision of the ${ }^{10} \mathrm{Be}$ measurements reported here $(3-9 \%)$ and in 
Licciardi et al. (2001) (3-14\%) varies according to the degree of isobaric ${ }^{10} \mathrm{~B}$ interference and on the counting time and ${ }^{10} \mathrm{Be}$ activity level. We rejected all measurements with high boron interference, thereby minimizing uncertainties imparted by this effect (see Licciardi, 2000). Analyses of 13 chemical blanks yielded ${ }^{10} \mathrm{Be} /{ }^{9} \mathrm{Be}$ ratios that range from 0.5 to $7.8 \times 10^{-15}$ and have a mean value of $3.2 \times 10^{-15}$, which is comparable to the ${ }^{10} \mathrm{Be} /{ }^{9} \mathrm{Be}$ background level of the accelerator mass spectrometer at the PRIME Lab facility (Sharma et al., 2000). These results indicate that laboratory contamination with meteoric ${ }^{10} \mathrm{Be}$ is not a problem for our samples.

Although we recognize that cosmogenic exposure ages are subject to revision as the accuracy of isotopic production rates and scaling factors continues to be refined (e.g., Licciardi et al., 1999; Stone, 2000; Dunai, 2000), these remaining uncertainties do not significantly hinder our ability to correlate between ${ }^{10} \mathrm{Be}$-dated glacial events in the ranges we examine. Uncertainties in the equivalence of various isotopic and calendric time scales, however, are important when comparing these ${ }^{10} \mathrm{Be}$ chronologies with other independently-dated records (e.g., radiocarbon, cosmogenic ${ }^{3} \mathrm{He}$ and ${ }^{36} \mathrm{Cl}$, layer-counted ice cores, etc.). At Yellowstone, the weighted mean ${ }^{3} \mathrm{He}$ and ${ }^{10} \mathrm{Be}$ ages obtained on the same landform agree within ca. $2 \%$ (Licciardi et al., 2001). This finding indicates that the ${ }^{3} \mathrm{He}$ and ${ }^{10} \mathrm{Be}$ ages are concordant within the combined error of production rates, scaling uncertainties, and measurement error, and provides important support for the accuracy of these dating techniques. Additional support for improved accuracy of cosmogenic ${ }^{10} \mathrm{Be}$ ages comes from recently documented convergence of ${ }^{10} \mathrm{Be}$ production rate estimates from various independent groups (Stone, 2000). Our suggested correlations with ${ }^{36} \mathrm{Cl}$-dated moraines in the Sierra Nevada are based on ages of Sierra Nevada moraines (F.M. Phillips, personal communication, 2002) that are calculated using recently revised ${ }^{36} \mathrm{Cl}$ production equations (Phillips et al., 2001). The validity of these ${ }^{36} \mathrm{Cl}$ production rates and resulting ages is supported by close agreement between unpublished ${ }^{36} \mathrm{Cl}$ ages (F.M. Phillips, personal communication, 2002) and independent radiocarbon age constraints (Clark and Gillespie, 1997) on the Recess Peak moraine in the Sierra Nevada. Swanson and Caffee (2001) derived significantly different estimates of cosmogenic ${ }^{36} \mathrm{Cl}$ production rates via individual pathways, and their production rates yield exposure ages that are younger by $30-40 \%$ at the Sierra 
Nevada sites. The cause of this apparent discrepancy remains unresolved, although Easterbrook (2003) has recently suggested that Swanson and Caffee (2001) overestimated the age of the radiocarbon-dated deglaciation surfaces used in their calibration by ca. 2000 years, which if true would require a recalculation of the Swanson-Caffee production rate values. 


\section{TABLE CAPTION}

Table DR1. Beryllium data for Wallowa moraines. All ${ }^{10}$ Be concentrations were determined by accelerator mass spectrometry (AMS) at the PRIME Lab facility at Purdue University (Sharma et al., 2000). Duplicate ${ }^{10} \mathrm{Be}$ measurements on splits of quartz from the same boulder, prepared separately for analysis, are labeled TTY-2A and TTY-2B, etc. "\#" indicates cosmogenic ${ }^{10} \mathrm{Be}$ concentrations normalized to the surface, and in the case of the Glacier Lake samples, corrected for shielding by snow and topography. Snow corrections assume an attenuation coefficient of $160 \mathrm{~g} \mathrm{~cm}^{-2}$, and sample thickness corrections assume an attenuation coefficient of $145 \mathrm{~g} \mathrm{~cm}^{-2}$ (Brown et al., 1992) and a rock density of 2.8 $\mathrm{g} \mathrm{cm}^{-3}$. Scaling factors are the ratio of production at sample locations to production at high latitudes at sea level, following Stone (2000). Quoted uncertainties incorporate analytical error only. See online text for additional details. 
Table DR1. Beryllium data for Wallowa moraines. Licciardi et al., submitted to Geology

\begin{tabular}{|c|c|c|c|c|c|c|c|c|c|}
\hline Sample & $\begin{array}{l}\text { Quartz } \\
\text { (g) }\end{array}$ & $\begin{array}{l}\text { Thickness } \\
\text { (cm) }\end{array}$ & $\begin{array}{l}\text { Altitude } \\
(\mathrm{km})\end{array}$ & $\begin{array}{l}\text { Latitude } \\
(\text { deg. N) }\end{array}$ & $\begin{array}{l}\text { Longitude } \\
\text { (deg. W) }\end{array}$ & $\begin{array}{c}{ }^{10} \mathrm{Be} \\
\left(10^{5} \text { at }^{-1}\right)\end{array}$ & $\begin{array}{c}{ }^{10} \mathrm{Be} \# \\
\left(10^{5} \text { at } \mathrm{g}^{-1}\right)\end{array}$ & $\begin{array}{l}\text { Scaling } \\
\text { factor }\end{array}$ & $\begin{array}{c}\text { Age } \\
\left({ }^{10} \mathrm{Be} \mathrm{ka}\right)\end{array}$ \\
\hline \multicolumn{10}{|c|}{ Wallowa Lake TTO unit } \\
\hline ТTO-2B & 21.204 & 1.75 & 1.530 & 45.321 & 117.196 & $3.63 \pm 0.16$ & $3.69 \pm 0.16$ & 3.51 & $20.7 \pm 0.9$ \\
\hline TTO-3B & 18.914 & 1.75 & 1.536 & 45.319 & 117.195 & $3.77 \pm 0.12$ & $3.83 \pm 0.13$ & 3.53 & $21.4 \pm 0.7$ \\
\hline TTO-7A & 30.051 & 2.00 & 1.524 & 45.326 & 117.199 & $3.73 \pm 0.27$ & $3.81 \pm 0.27$ & 3.50 & $21.4 \pm 1.5$ \\
\hline ТTO-9B & 30.419 & 1.00 & 1.509 & 45.328 & 117.200 & $3.55 \pm 0.20$ & $3.59 \pm 0.20$ & 3.46 & $20.4 \pm 1.1$ \\
\hline TTO-10B & 23.659 & 1.25 & 1.524 & 45.326 & 117.199 & $3.99 \pm 0.24$ & $4.04 \pm 0.24$ & 3.50 & $22.7 \pm 1.3$ \\
\hline TTO-11A & 27.012 & 1.50 & 1.481 & 45.333 & 117.205 & $3.73 \pm 0.21$ & $3.78 \pm 0.22$ & 3.39 & $22.0 \pm 1.3$ \\
\hline \multicolumn{10}{|c|}{ Wallowa Lake TTY unit } \\
\hline TTY-1B & 19.761 & 1.75 & 1.558 & 45.312 & 117.193 & $2.96 \pm 0.18$ & $3.02 \pm 0.18$ & 3.59 & $16.5 \pm 1.0$ \\
\hline TTY-2A & 23.023 & 1.75 & 1.551 & 45.314 & 117.194 & $1.90 \pm 0.16$ & $1.93 \pm 0.16$ & 3.57 & $10.6 \pm 0.9$ \\
\hline TTY-2B & 21.328 & 1.75 & 1.551 & 45.314 & 117.194 & $2.35 \pm 0.19$ & $2.39 \pm 0.20$ & 3.57 & $13.2 \pm 1.1$ \\
\hline TTY-3B & 30.015 & 1.75 & 1.542 & 45.317 & 117.195 & $2.98 \pm 0.24$ & $3.03 \pm 0.24$ & 3.55 & $16.8 \pm 1.3$ \\
\hline TTY-6A & 32.020 & 2.00 & 1.524 & 45.325 & 117.199 & $2.85 \pm 0.21$ & $2.91 \pm 0.21$ & 3.50 & $16.4 \pm 1.2$ \\
\hline TTY-8A & 28.372 & 2.00 & 1.498 & 45.329 & 117.202 & $3.66 \pm 0.27$ & $3.73 \pm 0.28$ & 3.43 & $21.4 \pm 1.6$ \\
\hline TTY-10B & 24.737 & 1.50 & 1.487 & 45.331 & 117.203 & $3.51 \pm 0.23$ & $3.57 \pm 0.24$ & 3.40 & $20.6 \pm 1.4$ \\
\hline TTY-12B & 23.095 & 1.50 & 1.509 & 45.317 & 117.221 & $3.51 \pm 0.19$ & $3.56 \pm 0.19$ & 3.46 & $20.3 \pm 1.1$ \\
\hline TTY-13B & 19.282 & 1.75 & 1.439 & 45.335 & 117.208 & $2.74 \pm 0.12$ & $2.79 \pm 0.13$ & 3.28 & $16.7 \pm 0.8$ \\
\hline \multicolumn{10}{|c|}{ Wallowa Lake WTO unit } \\
\hline WTO-1B & 22.134 & 1.75 & 1.475 & 45.324 & 117.222 & $2.94 \pm 0.14$ & $2.99 \pm 0.14$ & 3.37 & $17.5 \pm 0.8$ \\
\hline WTO-1C & 21.170 & 1.75 & 1.475 & 45.324 & 117.222 & $3.13 \pm 0.14$ & $3.18 \pm 0.15$ & 3.37 & $18.6 \pm 0.9$ \\
\hline WTO-3B & 29.526 & 1.75 & 1.466 & 45.325 & 117.222 & $2.65 \pm 0.15$ & $2.69 \pm 0.15$ & 3.35 & $15.8 \pm 0.9$ \\
\hline WTO-4A & 24.718 & 1.75 & 1.460 & 45.326 & 117.223 & $2.97 \pm 0.13$ & $3.02 \pm 0.13$ & 3.33 & $17.9 \pm 0.8$ \\
\hline WTO-5A & 30.811 & 1.75 & 1.454 & 45.326 & 117.223 & $2.82 \pm 0.10$ & $2.86 \pm 0.10$ & 3.32 & $17.0 \pm 0.6$ \\
\hline WTO-9B & 18.676 & 2.00 & 1.405 & 45.337 & 117.216 & $2.60 \pm 0.16$ & $2.65 \pm 0.16$ & 3.20 & $16.3 \pm 1.0$ \\
\hline \multicolumn{10}{|c|}{ Glacier Lake moraine } \\
\hline GL-1 & 30.545 & 1.50 & 2.512 & 45.158 & 117.283 & $3.63 \pm 0.15$ & $3.98 \pm 0.17$ & 6.98 & $11.2 \pm 0.5$ \\
\hline GL-2 & 29.098 & 1.50 & 2.506 & 45.159 & 117.284 & $0.67 \pm 0.06$ & $0.74 \pm 0.07$ & 6.95 & $2.1 \pm 0.2$ \\
\hline GL-3 & 25.272 & 1.50 & 2.509 & 45.159 & 117.284 & $3.01 \pm 0.12$ & $3.27 \pm 0.13$ & 6.97 & $9.2 \pm 0.4$ \\
\hline GL-5 & 30.111 & 2.50 & 2.504 & 45.160 & 117.285 & $3.24 \pm 0.20$ & $3.48 \pm 0.22$ & 6.94 & $9.9 \pm 0.6$ \\
\hline GL-5C & 22.887 & 2.50 & 2.504 & 45.160 & 117.285 & $3.48 \pm 0.19$ & $3.75 \pm 0.20$ & 6.94 & $10.6 \pm 0.6$ \\
\hline GL-6C & 19.617 & 1.50 & 2.503 & 45.160 & 117.285 & $4.26 \pm 0.35$ & $4.67 \pm 0.39$ & 6.94 & $13.2 \pm 1.1$ \\
\hline GL-7B & 40.060 & 1.00 & 2.502 & 45.160 & 117.284 & $3.51 \pm 0.19$ & $3.93 \pm 0.22$ & 6.94 & $11.1 \pm 0.6$ \\
\hline GL-7C & 29.658 & 1.00 & 2.502 & 45.160 & 117.284 & $3.44 \pm 0.32$ & $3.86 \pm 0.36$ & 6.94 & $10.9 \pm 1.0$ \\
\hline
\end{tabular}




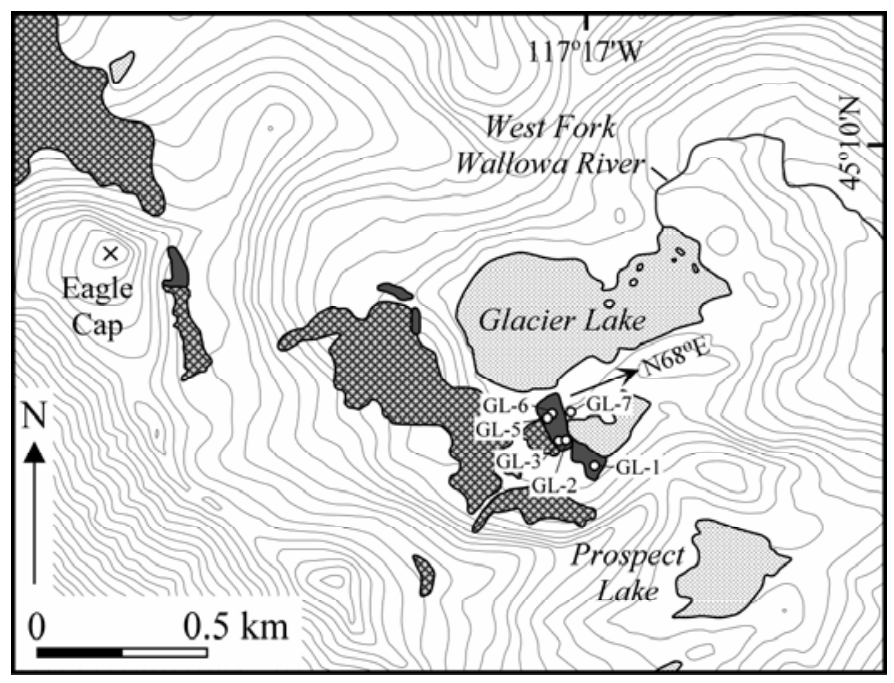

\section{FIGURE CAPTION}

Figure DR1. Glacial deposits in Glacier Lake cirque area. Dark gray shading_Glacier Lake moraines; hatched pattern — moraines thought to be Neoglacial in age (Kiver, 1974); open circles—locations of surface boulders and polished bedrock sampled for ${ }^{10} \mathrm{Be}$ exposure dating; arrow—orientation of striations on polished bedrock surfaces south of Glacier Lake. Base map has $20 \mathrm{~m}$ contour interval. Adapted from Kiver (1974). 


\section{REFERENCES CITED (GSA Data Repository item 2003\#\#)}

Bevington, P.R., and Robinson, D.K., 1992, Data reduction and error analysis for the physical sciences: Boston, WCB/McGraw-Hill, 328 p.

Brown, E.T., Brook, E.J., Raisbeck, G.M., Yiou, F., and Kurz, M.D., 1992, Effective attenuation lengths of cosmic rays producing ${ }^{10} \mathrm{Be}$ and ${ }^{26} \mathrm{Al}$ in quartz: Implications for exposure age dating: Geophysical Research Letters, v. 19, p. 369-372.

Clark, D.H., and Gillespie, A.R., 1997, Timing and significance of late-glacial and Holocene cirque glaciation in the Sierra Nevada, California: Quaternary International, v. 38/39, p. 21-38.

Dunai, T.J., 2000, Scaling factors for production rates of in situ produced cosmogenic nuclides: A critical reevaluation: Earth and Planetary Science Letters, v. 176, p. 157-169.

Easterbrook, D.J., 2003, Comment on the paper "Determination of ${ }^{36} \mathrm{Cl}$ production rates from the welldated deglaciation surfaces of Whidbey and Fidalgo Islands, Washington” by T.W. Swanson and M.C. Caffee: Quaternary Research, v. 59, p. 132-134.

Gosse, J.C., and Phillips, F.M., 2001, Terrestrial in situ cosmogenic nuclides: Theory and application: Quaternary Science Reviews, v. 20, p. 1475-1560.

Gosse, J.C., Evenson, E.B., Klein, J., Lawn, B., and Middleton, R., 1995a, Precise cosmogenic ${ }^{10}$ Be measurements in western North America: Support for a global Younger Dryas cooling event: Geology, v. 23, p. 877-880.

Gosse, J.C., Klein, J., Evenson, E.B., Lawn, B., and Middleton, R., 1995b, Beryllium-10 dating of the duration and retreat of the last Pinedale glacial sequence: Science, v. 268, p. 1329-1333.

Kiver, E.P., 1974, Holocene glaciation in the Wallowa Mountains, Oregon, in Mahaney, W.C., ed., Quaternary environments: Proceedings of a symposium: Geographical Monograph 5, York University, p. 169-195.

Kohl, C. P., and Nishiizumi, K., 1992, Chemical isolation of quartz for measurement of in-situ-produced cosmogenic nuclides: Geochimica et Cosmochimica Acta, v. 56, p. 3583-3587. 
Lal, D., 1991, Cosmic ray labeling of erosion surfaces: In-situ nuclide production rates and erosion models: Earth and Planetary Science Letters, v. 104, p. 424-439.

Licciardi, J.M., 2000, Alpine glacier and pluvial lake records of late Pleistocene climate variability in the western United States [Ph.D. thesis]: Corvallis, Oregon State University, 155 p.

Licciardi, J.M., Kurz, M.D., Clark, P.U., and Brook, E.J., 1999, Calibration of cosmogenic ${ }^{3} \mathrm{He}$ production rates from Holocene lava flows in Oregon, USA, and effects of the Earth's magnetic field: Earth and Planetary Science Letters, v. 172, p. 261-271.

Licciardi, J.M., Clark, P.U., Brook, E.J., Pierce, K.L., Kurz, M.D., Elmore, D., and Sharma, P., 2001, Cosmogenic ${ }^{3} \mathrm{He}$ and ${ }^{10} \mathrm{Be}$ chronologies of the late Pinedale northern Yellowstone ice cap, Montana, USA: Geology, v. 29, p. 1095-1098.

Middleton, R., Brown, L., Dezfouly-Arjomandy, B., and Klein, J., 1993, On ${ }^{10}$ Be standards and the half life of ${ }^{10}$ Be: Nuclear Instruments and Methods in Physics Research, v. B82, p. 399-403.

Phillips, F.M., Stone, W.D., and Fabryka-Martin, J.T., 2001, An improved approach to calculating lowenergy cosmic-ray neutron fluxes near the land/atmosphere interface: Chemical Geology, v. 175, p. 689-701.

Sharma, P., Bourgeois, M., Elmore, D., Granger, D., Lipschutz, M.E., Ma, X., Miller, T., Mueller, K., Rickey, F., Simms, P., and Vogt, S., 2000, PRIME Lab AMS performance, upgrades, and research applications: Nuclear Instruments and Methods in Physics Research, v. B172, p. 112-123.

Stone, J.O., 2000, Air pressure and cosmogenic isotope production: Journal of Geophysical Research, v. 105, p. 23 753-23 759.

Swanson, T.W., and Caffee, M.L., 2001, Determination of ${ }^{36} \mathrm{Cl}$ production rates derived from the welldated deglaciation surfaces of Whidbey and Fidalgo Islands, Washington: Quaternary Research, v. 56, p. 366-382. 
